\title{
Effect of fiber extraction methods on some properties of kenaf bast fiber
}

\begin{abstract}
The objective of this study was to investigate the effect of different extraction methods on the fiber morphology, density, chemical composition and tensile strength of kenaf bast fiber. Kena fbast fibers were extracted using different methods (crude, decorticated, water retted, $5 \%$ sodium hydroxide retted and $5 \%$ benzoate retted) and their physicochemical characteristics were investigated. The morphological characteristics showed a significantly reduced lumen diameter and increased cell wall thickness after treated with $\mathrm{NaOH}$ at $5 \%$. On the other hand, increased lumen diameter and a decreased cell wall thickness were observed with the decorticated and water retted bast fibers. A slight increase in fiber density was observed for $\mathrm{NaOH}$ and benzoate retted bast fibers indicating cell wall densification. Interestingly, the extraction methods used in this study produced bast fibers with high cellulose content and low sugar and starch due to the removal of wax, oil, pectin and hemicelluloses. Regarding the tensile strength, the water retted bast fibers showed highest tensile strength (426.05 MPa), while there was one no difference between decorticated and $\mathrm{NaOH}$ retted fibers (386.83 and $393.03 \mathrm{MPa}$, respectively).
\end{abstract}

Keyword: Kenaf; Decortications; Density; Fiber morphology; Chemical constituent; Tensile strength 